\author{
Abstracta Iranica \\ Abstracta Iranica Revue bibliographique pour le domaine irano-aryen \\ Volume 37-38-39 | 2018 \\ Comptes rendus des publications de 2014-2016
}

\title{
Valerie Gonzalez. Aesthetic Hybridity in Mughal Painting, 1526 - 1658
}

\section{Iván Szántó}

\section{(2) OpenEdition \\ 1 Journals}

\section{Electronic version}

URL: http://journals.openedition.org/abstractairanica/42744

DOI: 10.4000/abstractairanica.42744

ISBN: 1961-960X

ISSN: 1961-960X

\section{Publisher:}

CNRS (UMR 7528 Mondes iraniens et indiens), Éditions de l'IFRI

Electronic reference

Iván Szántó, « Valerie Gonzalez. Aesthetic Hybridity in Mughal Painting, 1526 - 1658 », Abstracta Iranica [Online], Volume 37-38-39 | 2018, document 3, Online since 10 March 2018, connection on 28 September 2020. URL : http://journals.openedition.org/abstractairanica/42744 ; DOI : https://doi.org/ 10.4000/abstractairanica.42744

This text was automatically generated on 28 September 2020

Tous droits réservés 


\title{
Valerie Gonzalez. Aesthetic Hybridity in Mughal Painting, 1526 $-1658$
}

\author{
Iván Szántó
}

\section{REFERENCES}

Valerie Gonzalez. Aesthetic Hybridity in Mughal Painting, 1526 - 1658, Farnham:

Ashgate, 2015, 318 p., 42 figs. ISBN: 978-1409412564.

1 Written with a wide intellectual scope and without fear of confrontation, this book addresses what its artist-scholar author considers to be fundamental flaws in the theoretical underpinning and methodology of Islamic art scholarship. Arguably, these have been responsible for hindering the ability of this branch of art studies to comprehensively interpret its subject since its introduction into Western academia at the past turn of the century. Thus, the book seeks to construe these deficiencies and argue for new research trajectories in order to remedy them. Consequently, it is not, first and foremost, about Mughal court painting as its title would imply, but rather a theoretical essay which utilises Mughal art as a testing agent on which to demonstrate a desired interpretive approach towards Islamic artworks in general. Accordingly, the book is divided into two parts, the first setting out epistemological preliminaries, as well as a historiographical and conceptual framework, while in the second part these techniques are applied to the analysis of Mughal visuality.

One of the core themes in Part 1 is the dominance of the art historical (or archaeological) approach in Islamic art studies at the expense of art criticism. After problematizing this phenomenon, the author goes on to demonstrate the failure of the archaeological method to get close to art's ontological self-referentiality, notwithstanding the impressive amount of external knowledge which it can gather to contextualise the artefacts under investigation. While criticising the presumed 
hegemony of the art historical/archaeological approach, the author underscores her indebtedness to other Western intellectual constructs (from the Deleuzian concept of synthesis to Merleau-Pontian hyperdialectics, Foucault's epistemology, and Derrida's aesthetic philosophy) because, as she argues, these provide the theoretical basis of our understanding of the hermeneutics of Western art, yet their universal validity has not been tested on Islamic art, in particular its figurative Persianate variety. From this stance, several proponents of the field, including Gülru Necipoğlu, David Roxburgh, Gauvin A. Bailey and Ebba Koch-and through them "institutional" Islamic art historiography at large-, are subjected to criticism, as much for their alleged refusal to engage with the aesthetic, poetic, and spiritual fundaments of art, as for their exclusivist and literal use of (not necessarily relevant) contemporary textual sources, their resistance to transculturalism, and their manifest or latent Eurocentrism.

Another major theme of Part 1 is hybridity, reintroducing it as a post-colonial notion and juxtaposing it with its conceptual opposite, i.e., non-hybridity. This paradigm serves the basis for Part 2 in which late $16^{\text {th }}$-century Mughal art is perceived to represent hybridity in the hybrid/non-hybrid binary, moving away from the nonhybrid heritage of Sultanate art through the experience of the likewise non-hybrid early-Safavid and Jesuit missionary arts, and gradually establishing its own non-hybrid synthesis which would be reached by the time of šāh Jahān. Mughal art, Gonzalez argues, can be defined only through this binary, as opposed to external circumstances, including historical or dynastic chronology. Consequently, the art of the first two Mughal rulers cannot be considered "Mughal art", because that little which survives from this period does not display any intrinsic "Mughal" characteristics and separate semiotics. It is the shift from its logocentric predecessors towards a mimetic representation and the turning away from the earlier "signaletic" portraiture to a new physiognomic one in which the singularity of Mughal pictorial arts can be articulated, concludes the author.

\section{AUTHORS}

\section{IVÁN SZÁNTÓ}

Eötvös Loránd University, Budapest \& Austrian Academy of Sciences, Vienne 